Canadian Studies in Population 41, no. 3-4 (2014): 117-134.

\title{
Complicating food security: Definitions, discourses, commitments
}

\author{
William Ramp ${ }^{1}$
}

\begin{abstract}
Food security is now commonly seen as one of the defining global issues of the century, intertwined with population and consumption shifts, climate change, environmental degradation, water scarcity, and the geopolitics attending globalization. Some analysts suggest that food security threats are so urgent that philosophical scruples must be set aside in order to concentrate all resources on developing and implementing radical strategies to avert a looming civilizational crisis. This article suggests that definitions of food security invoke commitments and have consequences, and that continued critical and conceptual attention to the language employed in food security research and policy is warranted.
\end{abstract}

Keywords: food security, food justice, sustainability, risk, discourse.

\section{Résumé}

De nos jours, la sécurité alimentaire est considérée comme l'enjeu déterminant du siècle, entrelacée avec les déplacements de population et de consommation, le changement climatique, la dégradation environnementale, le manque d'eau et la situation géopolitique mondiale. Certains analystes suggèrent que la sécurité alimentaire serait tellement urgente qu’il faudrait mettre de côté les scrupules philosophiques pour concentrer toutes les ressources sur les stratégies radicales dans le but de parer à une crise civilisationnelle imminente. Cet article laisse penser que les définitions de sécurité alimentaire invoquent des engagements et des conséquences et que l'attention continue et conceptuelle au langage utilisé dans la recherche et politique sur la sécurité alimentaire est justifiée.

Mots-clés : sécurité alimentaire, justice alimentaire, durabilité, risque, discours

\section{Food security: Setting and complicating the stage}

That food security is a pressing global issue increasingly appears self-evident: climate change, water scarcity, geopolitics, and the vulnerability of a globalized food system all present clear threats to food supply, especially for urbanized societies. This combination of obviousness and urgency fuels much discussion, thoughtful and otherwise, but can also allow shared assumptions to be construed as factual conclusions. This article takes food security issues seriously, though it does not aspire to identify optimal solutions to them. It does aspire to aid in that identification - but by troubling the process, arguing that the language of food security research, activism, and policy, as generated in institutional and practical settings, shapes problem definition and frames the range and type of acceptable responses, in ways not always self-evident. This is inescapable, and scientific method alone cannot resolve it, but awareness of it may broaden the range of possibility for scientific, policy, and practical work and enhance the wisdom of that work.

1. Prentice Research Affiliate, Prentice Institute for Global Population \& Economy, University of Lethbridge, 4401 University Drive West, Lethbridge AB Canada T1K 3M4. Email: ramp@uleth.ca. 
In 2000, Norman Borlaug, father of the Green Revolution and advocate of high-output agricultural modernization, asserted that agricultural scientists had a "moral obligation to warn political, educational, and religious leaders about the magnitude and seriousness of the arable land, food, population, and environmental problems that lie ahead;" problems which must be "addressed in a forthright manner" and which entail a "need to bring common sense into the debate on agricultural science and technology — and the sooner the better!" (Borlaug 2000: 490). A similar bluntness marks political journalist Gwynne Dyer's recent and startling proposal for a food-secure future in our present climatic predicament:

We can go on in the present patchwork way, with a bit of conservation here and some more renewable energy there, in which case we are heading for population collapse through global famine, and probably civilizational collapse as well, because of the attendant wars, well before 2100 . Or we can try to float free from our current dependence on the natural cycles. Use the scientific and technological capabilities of our current civilization to reduce our pressure on the natural world radically. Stop growing or catching our food, for example, and learn to produce it on an industrial scale through biotechnology instead.

[...] more romantic environmentalists [...] think we can avoid disaster just by learning to "live lightly on the planet." [...] That option disappeared at the latest in the 1960s... (Dyer 2012).

The options Dyer advances - full-scale industrial production of proteins and carbohydrates, and geo-engineering - might make even Borlaug blanch, but both writers share a sense of urgency, and both have ideas about where "common sense" should part ways with romanticism. But in practice, what initiatives would get sorted into these respective categories, and by what agencies? I want to suggest that "hard-headed" approaches to our shared predicament, if untroubled by such questions, could leave unchallenged tendentious representations of that predicament, how we share it, how we respond to it, and who or what we are in responding, impairing our ability to recognize or anticipate unintended consequences. There is no inoculation against unexamined assumptions or taken-forgranted conceptual frames. Thus, responses to food security issues need always involve double-work: engaging with issues and reflecting on the terms of engagement, which may not always be immediately evident. The payoff might be not only better awareness of the multidimensionality of food security issues, but also a more critical sense of how issue construction could affect choices made in science and policy.

The term "food security" is defined and used variously in scientific, policy, journalistic and everyday language. Statements about it constitute social facts (Durkheim [1895] 1982: 50-59), events in the formation of collective representations, and co-ordinated action. They invoke and reproduce specific aspects of the human social condition, linking food security to concerns about resources, technologies, values, sociability, and the organization of space and time. Food security terms are defined and deployed, in relation to other terminology, in the course of specific institutional, organizational, or political practices. This deployment also forms our subjective constitution and orientation as agents in meaningful fields of action encompassing the social, political, economic, and cultural dimensions of food. The following selective survey of some popular representations of food security begins to suggest how even basic and pragmatic statements about it mobilize ontological, epistemological, and perspectival commitments (Bonner 1997: 57, 60-67) within particular settings, practices, and processes (Latour 2000). Such commitments recommend ways of acting on food security as a legitimate public concern, a scientific topic, or a policy target. In short, food security is produced as a documentary reality in terms of presuppositional frames and specific social and organizational priorities, whether those of informal groups or of abstracted systems that assert and operationalize definitive general principles (Smith 1974). 
Complicating food security: Definitions, discourses, commitments

\section{A technological achievement and a deliverable service-commodity}

From the 1930s to the 1970s, issues of food supply were commonly represented as challenges of modernization amenable to scientific, technological, and educative solution, backed by states or major corporations (Hewitt de Alcantara 1974; Shiva 1992; Parayil 2003; Westerman 2010). Modernization language still has power, as Borlaug's work, and the public relations materials of many corporate and government agencies, attest. These tend to represent food as a "deliverable" —a supply of affordable, reliable quality commodities provided by high-output agriculture and technologically advanced processing. By extension, food security itself, in the language of technocratic mission statements, can be styled a policy deliverable: a state of well-being that policy-informed by science, technology, and enterprise — can facilitate. What is (to be) delivered, then, is both a reliable supply of consumer items and a technologically secured universe of consumption. A recent food security modelling exercise carried out by Foresight, the UK Government Office for Science's think tank, resulted in a report that checks such optimism with a sobering look at environmental limits and complexities, yet remains focused on "addressing these in a pragmatic way" that will "[balance] demand and supply sustainably" (Foresight 2011: 9).

\section{An effect of private property rights or a byproduct of market, trade or pricing reform}

William Bernstein writes in The Birth of Plenty that "[i]ndividuals without property are susceptible to starvation, and it is much easier to bend the fearful and hungry to the will of the state" (2010: 53). Similarly, others assert that motivation for innovation and productivity depends on clear, respected and enforced individual property rights (e.g., De Soto 2000), that first-world agricultural subsidies undermine both appropriate market responses at home and self-sufficiency elsewhere (Ostria 2013), and by extension, that free and undistorted markets constitute a human right. Moyo (2009) argues that development aid impoverishes agriculture and corrupts states and economies. Free trade and robust property rights, by contrast, are said to facilitate workable solutions to agricultural problems, and underwrite efficient distribution systems sensitive to market signals. Such claims reflect both a resurgent liberal economic philosophy and also frustration with the perceived failure of many foreign aid initiatives.

\section{A form or a consequence of social justice}

Conversely, access to food and water may be defined as human rights, which trump private property rights and market freedoms, and food itself as a sort of commons (a common right). In this rendition, food security is represented not only as a matter of provision, but also as one of social justice and fairness: feeding the world equitably, and sharing both benefits and risks (Gottlieb and Joshi 2010). Popular among many NGOs and anti-globalization activists, the framing of food security as a justice issue can raise further questions about how justice is defined and by whom; whether justice itself is always justly formulated.

\section{An element of sovereignty}

Food sovereignty (a term originating with the international peasant movement La Via Campesina) designates the ability of a people to act autonomously to feed itself or produce its own food; an element of popular sovereignty. But it can also be defined in nationalist terms: securing a national food supply, or freedom from dependence on extra-national food sources (e.g., Swaminathan 2010: 11). Both definitions invoke forms of agency, the ability of popular or national communities, or states, to act effectively to produce, secure, or access food. 


\section{Canary in a coal mine}

Intensifying discussion of food security is itself representable as a second-order symptom, indicating a growing collective anxiety and popular skepticism about the capacities and consequences of technological modernization, and about the ability of states and international bodies to serve as effective vehicles for it, or for any other solution to environmental or food crises. Even in prosperous societies, for example, famine is now represented as a prospective threat to the survival of humanity with several possible triggers, some already pulled.

\section{An opportunity for synthetic thinking and action}

The Foresight report (2011) exemplifies recent attempts to synthesize ecological thinking with crop and genetic science, and economic and social planning. M.S. Swaminathan, a pioneer with Borlaug of the Green Revolution in India, argues for an integrative and internationalist approach to food security, one also sensitive to the knowledge and priorities of small-scale, local producers; to indigenous land and water arrangements, and to the empowerment of women and youth (2010). He now promotes an "ever-green revolution" balancing yield and soil conservation, and "ecotechnology," a farming-systems rather than commodity-centred approach to technological development, as a "backbone of the rural livelihood system" (Swaminathan 2010). He also aspires to replace the term "food security" with nutrition security-physical and economic access to a balanced diet and safe drinking water by all people at all times (2010: 46, 70-74, 188, 212-215). To these ends, he pays particular attention to demographic matters: the interplay of gender and age structure, socioeconomic status, income, and consumption trends (2010: 48, 190). He does not foresake his Green Revolution legacy, but incorporates it into what might be called a hybrid approach, reflecting close contacts with small agricultural producers as well as scientists and policymakers.

\section{Rhetorics of food security}

These various representations of food security form vigorously debated elements of the politics of food, lending themselves to particular social strategies and suggesting different outcomes and consequences. These are evident in the rhetorical shape even of statements which purport to define food security in consensus terms, as the following examples demonstrate:

\section{- United Nations Food and Agriculture Organization}

"Food security exists when all people, at all times, have physical, social and economic access to sufficient, safe and nutritious food to meet their dietary needs and food preferences for an active and healthy life" (FAO 2003: 29).

\section{- United States Department of Agriculture}

"Food security for a household means access by all members at all times to enough food for an active, healthy life. Food security includes at a minimum (1) the ready availability of nutritionally adequate and safe foods, and (2) an assured ability to acquire acceptable foods in socially acceptable ways (that is, without resorting to emergency food supplies, scavenging, stealing, or other coping strategies)" (USDA 2012). 


\section{- Centre for Studies in Food Security (CSFS), Ryerson University, Toronto}

- Availability - sufficient food for all people at all times;

- Accessibility - physical and economic access to food for all at all times;

- Adequacy - access to food that is nutritious and safe, and produced in environmentally sustainable ways;

- Acceptability - access to culturally acceptable food, which is produced and obtained in ways that do not compromise people's dignity, self-respect or human rights;

- Agency - the policies and processes that enable the achievement of food security (Centre for Studies in Food Security 2012).

The USDA and FAO statements share some wording, derived from a 1996 Food Summit statement. But note the USDA statement's shift from the term people to members of households, configuring food security as a public issue relating to private consumption. The term access, complemented by the phrase "ability to acquire," makes the USDA statement compatible with a commodified definition of food; an interpretive possibility strengthened by the phrase "socially acceptable" — which, though unspecified, is used to rule out unacceptable food-acquisitive "coping strategies" not involving purchase of food on the retail market, and involving actions which can be represented as undermining said markets. Such wording naturalizes the idea that food security involves security of the ability to purchase food, by private individuals and households, reflecting the importance the USDA places on commodity production.

The CSFS list links sustainability to environmental and production issues in a manner also extensible to matters of transportation, consumption, population health, economic arrangements, and regulatory regimes. It also positions food security in terms of utilization and nutrition, not just supply (as does Swaminathan 2010). The CSFS definition uniquely highlights acceptability and agency: beneficiaries of food security are not population aggregates to be supplied with or given access to foodstuffs, but subjects with collective as well as individual rights to judge acceptability. It positions food security explicitly as a justice rather than management issue (see also FEC 2010), and planning as something to be undertaken by people who claim food rights for themselves, rather than as something done for them or on their behalf. This can beg questions about the political as well as legal adjudication of conflicting claims and rights: the location of those who pose such questions in relation to those to whom the questions refer. Sustainability-oriented and environmentalist definitions of food security like that of the CSFS are popular in social justice circles but not entirely exclusive to them. Advocates of large-scale, technology-centric agriculture and processing have also argued that these have a positive cumulative environmental footprint, and a better overall safety profile than diverse small-scale production and processing, and defenders of commercial food systems can invoke sustainability in relation to profitability.

\section{Linked issues and tangled webs}

Despite political, definitional, and other differences, the more recent food security discussions tend to highlight the entanglement of food system vulnerabilities with other issues, such as climate change, water shortages, civil and military conflict, population migration, and land disputes. This encourages efforts to synthesize a vast amount of information and competing priorities. Dyer focuses on factors which contribute to vicious ecological and political circles: e.g., how drought-driven depletion of aquifers, deforestation, erosion and soil degradation can be both causes and demographic 
consequences of land clearing by displaced populations. Water deficits and drought-related crop shortages already affect global commodity markets, rendering even powerful economies vulnerable (Reuters 2012; Brown 2011: 23-27). Geopolitical rivalry and military operations may be climaterelated and can threaten food systems. Several studies explore the complex links between food supply and demographic issues (e.g., Zuberi and Thomas 2012): determining global or regional carrying capacity involves attention not only to sheer population numbers or rates of increase, but also to specific consequences of birth rates and generational cohorts, migration, urbanization, and the changing culinary and health expectations of new urbanites and middle classes (e.g., Swaminathan 2010). Many of these discussions involve forecasting: policing, agricultural protection and public health planning now include prospective identification and management of "threats" or "risks" such as bioterrorism, agroterrorism, or industrial espionage. The categories of threat and risk are also applied to disease vectors affecting agriculture or food safety, to resource geopolitics, to transportation vulnerabilities affecting food and agricultural supplies, and to problems of large-scale food storage, all fed by technological developments in international transportation and globalization of the commercial food economy. They incite a co-ordinated emphasis on securitization (Saunders 2011; Swaminathan 2010: 13; Sintchenko, n.d.[2005?]), ${ }^{2}$ from the farm gate to the retail outlet. ${ }^{3}$

Also implicated in the construction of food issues are property regimes which facilitate commodification of food and the growth of a globalized food economy. Commodities - forms of "disposable property" represented by "commercial instruments" (Weber 1968: 141-142) —are often taken for granted, but they are neither natural phenomena nor conceptual universals. They are defined, produced, and accumulated in concrete, historical circumstances, such as the reformation of Mexican property law facilitating conversion of indigenous collective landholding (the "ejido" sector) into private property tenure (Stephen 1998; Barnes 2009), allowing land-assembly for commercialized production and "liberating" those exiting the land to enter a world of mobile wage labour and commodified food consumption. Commodification of water and genetic information, breeders' rights and tradeable water rights can spark political and policy controversies. Assembly of agricultural land by large commercial interests - the so called international "land rush" — engages both a global framework of trade and other agreements, and national and local politics (Burgis and Blas 2009; Rakotondrainibe 2012). Conceiving of land as a seedbed to which "inputs" are added and from which "outputs" are forecasted, harvested, and processed reflects one aspect of this commodification process; movements to defend common land rights, or encroachment on public land by displaced populations, indicate others (e.g., Draper 2011). Food security is also definable only in relation to existing or possible systems of production, distribution, and consumption. Subsistence production, local distribution, and non-industrial processing and preparation can persist alongside large-scale commercial agriculture and global commodity and processing oligopolies. Both can contribute to pathdependence, connecting past and future in sustainable or unsustainable ways. How they relate to each other depends on specific histories of contested rights and benefits.

Thus, food security is much more than the provision of nutritional materials to biological populations. The Foresight report (2011) concludes that the food system "cannot be considered in isolation from other major global policy objectives" (164), and calls for "concerted action across several policy domains" to balance future demand and supply sustainably, address market volatility, end

2. My use of the term "securitization" generally follows that advanced by Walby and Hier (2005).

3. Risks posed by individual or household food consumption practices are more likely to be treated as private responsibilities or public education matters (the inculcation of self-surveillance) than as security issues involving policing intervention. 
hunger, reduce greenhouse gas emissions, and maintain biodiversity (16-31). It warns that in recognizing the need for "urgent action [that] policy-makers should not lose sight of major failings in the food systems that exist today" (9), e.g., market volatility, unsustainable production practices, and institutional mechanisms perpetuating chronic hunger - all of which, of course, interact. Nonetheless, food security recommendations reflecting decontextualized models of property, trade, production, and human needs still make their appearance.

\section{The long view: The agro-industrial system and path-dependencies}

Despite these complexities, the history of commercial food production shows a clear trend toward concentration of ownership, consolidation of productive units, intensification, vertical and horizontal integration, reliance on fossil-fuelled technologies, and technocratic planning and management. These form an international "agro-industrial complex," which reconfigures farming as the production of separable and recombinant elements (e.g., fibre, starches, bovine and other proteins, nutraceuticals, oils, fuels) and the mobilization of intellectual property - an analytic and materials-management process through which food is de-localized (Winson 2013; Montanari 1996). The scale of this complex also facilitates a physical and communicative separation of production and consumption (Coff et al. 2008), limiting consumers' understanding of how, where, and under what conditions their food is produced, transported, or processed - a condition exacerbated by the securitization of agricultural production and processing. Commodification of ("proprietary") information also feeds this syndrome. Limited consumer agency, itself subject to management, feeds mutual frustration: industry and regulatory agencies decry "consumer ignorance;" consumers allege coverups. Use of terms like "outrage management" in risk-assessment literature does little to allay the latter concerns.

Another consequence of large commercial-industrial food systems is a scaling-up of regulatory and support frameworks, which now apply both nationally and (via trade agreements or bodies like the EU) internationally. Local food production and foodways are challenged by regulatory and planning regimes more amenable to technology-intensive, large-scale, or export-oriented production. Globalized production and distribution, in concert with national or geopolitical political agendas, encourage subsidy and market mechanisms which disadvantage vulnerable or "peripheral"producers and consumers. Governments often encourage scaling-up food production and processing in the name of competitive efficiencies, but this does not reliably generate long-term corporate or industrial sustainability - witness the continued reliance of US agricultural production on subsidies, or the troubled history of Canada's second-largest beef processor (Cross 2012; Toronto Star 2012). Internationalization of the industrial food system, in uneasy co-ordination with producer lobbies, exportoriented trade policies, and national subsidy regimes, raises questions about the possibility of popular food sovereignty or food democracy (see McKeon 2013), and whether the idea of food security could serve a "legitimizing ideology" to de-politicize responses to prospective food shortages (Koç and Bas 2012: 192). Consolidation of commercialized and technology-intensive agricultural units accelerates rural depopulation and rural-urban political imbalance, while internationalized commodity markets and oligopolies favour urban centres and encourage urban-oriented regulation, planning, and management. Political economies of scale affect both national and international food policy: close relations between governments, corporations, and lobby groups dominated by larger players, and migration of key personnel between them. At the policy trough, some piglets get shouldered aside. Democratic discussion of food policy is also threatened by knowledge gaps between the spheres of production, regulation, and consumption: large systems generate technocratic elites and special- 
ized knowledge difficult for average citizens to grasp. Finally, centralized, highly capitalized hightechnology systems generate path-dependencies that become "necessities" in ways that work against democratic communication and debate (Winner 1986).

This complex and conflictual legacy demands careful analysis. But the time, resources, and social space for it may be threatened in future by climate, economic and political crises, or geopolitical and demographic tensions, in all of which food may become both weapon and target. Planning efforts to address large-scale system issues, especially if they are undertaken by scientific, technocratic, or policy elites, also face a legitimation crisis, driven by a new wave of anti-elite populism and conspiracy theorizing (Ramp and Harrison 2012; Wilson 1977, 2001). This could become endemic if such systems fail to protect or benefit people in ways meaningful to them, undermining even food democracy advocates who share a skepticism of elites. When multiple crises converge with a weakened civic sphere, popular sense-making can morph into paranoia or scapegoating as easily as it can into democratic consciousness-raising. An optimist on this issue, Swaminathan (2010: 10-11), places government at the "commanding height" of an enlightened national food security system. But big-picture solutions to the coming food crisis, such as those advocated by Dyer (2012), Swaminathan (2010), or Foresight (2011), would demand co-ordination between government, business, scientific institutions, and civil society organizations, capitalization, and further development of expert systems and knowledge. None of these can be assured, precisely because of the converging crises they are meant to address.

\section{Food ontologies and project politics}

Calls for diversity and localism in contemporary food systems have been countered by defenses of the benefits for food safety, availability and quality of standardized regulation and an export-oriented food system, and claims that trade can pull diverse peoples together in a new cosmopolitanism. Likewise, advocates of genetic engineering and technological intensification can cite the objectivity and universality of the scientific method. Such justifications are shadowed by allegations that global trade marginalizes as much as it universalizes, and that ethnocentric assumptions (e.g., about nutrition and food acceptability) can be misrepresented as universal in scientific work. These justifications can also trivialize differences in cultural meaning as less important than underlying biological, economic, or demographic "realities." However, such realities are themselves always already cultural: they are meaningful only through language, and food systems, science, and policy are inseparable from the institutional, symbolic, and praxiological fabric of human life (Montanari 1996; Latour 2000). The process by which food is made meaningful is also ontological. How we think about and act in relation to food is part of how we identify what it is to exist and what is necessary to be human (Douglas 2002).

The example of famine illustrates this point. Its periodic visitations, inscribed in the foodways and lore of preindustrial agricultural peoples (Montanari 1996), encouraged a sense of existence as being providential, dependent on forces beyond human control; of food and life as matters of gratitude, gift, and relation (Visser 2008; Robinson 2012). ${ }^{4}$ But this universe is now distant from contem-

4. Conversely, famine could be envisaged as a consequence of ingratitude or dis-relation. Repentance was less about controlling providence than a return to relation, parallel to a return of rains or fertility: the Biblical prophet Hosea spoke of God "raining righteousness" on those who sowed it. But God's sun also rose on evil and good, and his rain fell on the just and unjust (Matthew 5:45); a providential understanding of famine and plenty did not ignore their arbitrariness, nor was gratitude was the only modality of response. Even within a providential cosmos, providence could be argued with or flouted. Dread and vengeance stalked repentance and reciprocity. Fear of hunger, and envy of the fat, generated a lore of greed, trickery, and revenge, and fantasies of prodigious feasting or cannibalism (Darnton 1984: 23-65). Hoarding and 
porary food security discourse, especially in the developed world, even when the prospect of future famine is raised (Fraser and Rimas 2010). Both technocratic and social justice representations of food security tend now to be framed in terms of control over resources or spaces: rendering resource supply dependable or spaces reliably safe. Aside from voices conveniently dismissible as fringe, food security discourse is not focused on trust in, gratitude toward, or protest against providence. Food democracy ideals may have certain roots in, say, the prophetic traditions of Abrahamic religions, but fear, envy, generosity or reciprocity are now subsumed under the language of objectives, outcomes, risks, or irrationalities. Criticism of trade inequities can resemble ancient reproofs of greed, but now rests on other grounds. Famine as a concrete visitation of cosmic will or fate is replaced by abstract famine risk. The former was feared, the latter is an object of assessment and intervention, subject to buman mitigation. Both Dyer's stark vision of an industrialized food system (2012), severed from any land base, and the sober language of the Foresight report (2011), share this newer outlook, which positions human cognition and agency centrally in terms of a field of objects and opportunities. It was born of an ontological reorientation of subjectivity around human rather than cosmic purpose and judgement that came to fruition in the Enlightenment (Darnton 1984: 195-213), though it had several variations. It displaced (but never entirely erased) providential cosmologies, re-visioning the natural world - and latterly also the social one-as assemblages of things or materials subject to empirical observation, rational analysis, and instrumental manipulation. Human-centric observation and reason underwrite aspirational plans "projected" on a world malleable in their image, in which the tool (as divine gift) is displaced by technology (as human construction), commensality by system co-ordination, obedience by self-discipline, and command by the abstract rule of efficiency (Alexander 2008; Novak 2008; Sawday 2008; Vernon 2007).

This reorientation is institutionalized practically in the analytic deconstruction and recombination of materials and of actions, and in componentization and system-engineering. Reconfiguring agriculture as input-output mechanisms, or of food provision as materials-management, activates a modernist ontology. Project orientation liberates human beings not only from gratitude and dependence but also from limitation - a liberation central to the expansive promethean energies of modern capitalism (see Albritton 2012), and of a modern science obedient to the impersonal discipline of rigorous observation and rational analysis but unfettered in topical reach and application. Paradoxically, a converse effect of this orientation is that human-produced systems can appear either as if natural mechanisms, or they themselves, are agents which curb, direct, or overwhelm human action. Natural processes can also be represented in the language of buman projects, as in the Foresight report's (2011) discussion of “ecosystem services:" climatic, hydrologic, and other processes, necessary to but not part of agriculture, which reproduce the atmospheric, water, biological and soil conditions under which it is possible. Calling them "services" in the language of modern management represents them as "providers" of benefits or, in market language, as "natural capital" for human activities. Reference to policy "indicators," "metrics," and "management tools" (Foresight 2011: 154) beg questions about how technological or management rationality could also affect the definition of, say, "empowerment."

The (2011) report's discussion of ecosystem services is actually intended to highlight the limitations of a decontextualized emphasis on technological solutions to food production issues, and these language choices could be called merely unfortunate. But cumulatively, they may reinforce ways of

cheating were staples of folktales and were pursued in economic life, stirring resentment in the (often rural) deprived and fear in the (often urban) fortunate (Huppert 1998: chs. VI, VII; Montanari 1996: 51-54, 69-70). 
thinking and modes of action that the report itself criticizes. The report supports a strengthened civil society role in democratic "system accountability" and enforceable right-to-food legislation, with the qualification that while civil society work "is welcome in terms of affirming values, it remains to be seen whether it leverages resources [my emphasis] to accelerate hunger reduction" (127). It also advocates that genetic modification, cloning, or nanotechnology should not be excluded from consideration "a priori on ethical or moral grounds," begging the question whether similar language could conceivably justify exclusion of "ethical and moral grounds" themselves as criteria for judging food security interventions $(11,42)$. On the other hand, the Foresight report treats markets as if they are mechanisms above human agency, best freed of distorting policy interventions. "Fair and fullyfunctioning markets" and "liberalised global trade arrangements" are represented as compatible goals (Foresight 2011: 166-168, 174). Volatility might require mitigating policy intervention, but for the most part, markets are represented as self-regulative signalling and distributive systems, abstract but naturalized mechanisms, rather than fields of intervention or systems of social relations and practices located in specific contexts. The possibility that competitive market freedom might itself lead to systemic "distortions" in food supply (socially irrational economic rationalities, crises in capital accumulation or circulation) or to distorted sociocultural arrangements (erosion of public regulatory capacity and of public goods, skewed distribution of wealth, commodification of human relations) is not addressed. Food itself is represented as "a unique class of commodity" (Foresight 2011: 10)— but a commodity nonetheless.

Swaminathan uses the language of twentieth-century modernizers to advocate increased crop yields and better nutrition through input-output efficiencies, biotechnology, biosphere management, and social management (Swaminathan 2010: 207), the goal being "biohappiness" (11). However, he contextualizes and counterbalances these imperatives: yield with quality and soil conservation; biotechnology with protection of naturally occurring varietal diversity, food safety, and farmers' property rights. He also seeks to integrate advanced science with local or traditional knowledge, economic priorities with social justice, and standardized planning or measurement with self-organization. Like the Foresight report, he calls for "co-ordinated thinking and action" about these (53). His weaving together of what might appear individually as incompatible priorities, in terms of numerous concrete examples, gives a cumulative sense of a trajectory somewhat different from the Foresight report's high-level modelling (Swaminathan, for example, advocates trade supports for small producers). It can impart some discomfort to readers expecting consistency with a given political line or language, but it shows how basic commitments and orientations at work in recent food security documents are not necessarily static or univocal. (I might add that in comparing elements of a modern ontology to its predecessors, I am not suggesting flight to a pre-modern Eden.) Ontologies have various practical and political manifestations, not all contradictory and some coexistent (Visser 2008), and may generate a mix of actions and consequences. ${ }^{5}$

5. Pre-modern societies practiced large-scale agriculture (A. Cuellar, University of Lethbridge 2012, personal communication), and medieval agricultural fairs exhibited "ferocious profiteering and regulation" (Fraser and Rimas 2010: 25), though neither is strictly comparable to modern economic or policy rationality. Today, local food markets coexist (albeit uneasily) with corporate retailing, and food executives seek to "fuse the credos of mass-market food makers and environmentalists" (Glassner 2007: 74; but compare to Johnston et al. 2009). The modern primacy of human-centric cognition and agency generates its own converse when human worlds are objectified in scientific study and intervention, and human initiative is subsumed under formal procedure and systems analysis (Alexander 2008; Foucault 1994). Commercial food production involves both technological and human management systems; food policy can be assessed in terms of outcome-based calculi, and consumer behavior analyzed in light of neuroscience or retail anthropology. 


\section{The securitization of food and population}

Nonetheless, I would suggest that there is a danger in articulating food issues primarily as matters of system/object analysis or control, both in the identification and management of risks, and in the designation of opportunities. The danger does not necessarily invalidate this work, but it begs careful reflection and civic vigilance. Both "security" and "risk" have military and policing referents involving managerial exercises of power, represented at once as technical matters and as preventative necessities, over individuals and populations. Securitization threatens a suspension of the political in a state of ongoing prospective emergency which "colonizes" the future (Beck 2002: 40; de Larrinaga and Doucet 2010; Neoclous and Rigakos 2011). This prospective orientation to the management of populations is not entirely new; it can be traced to eighteenth-century Physiocratic $^{6}$ use of the term "population" to identify a body of people in need of study and subject to ameliorative and ordering interventions to enhance "welfare:" that is, happiness and productivity (compare to Swaminathan's term "biohappiness;" 2010). Subsequent developments in population studies and policy reflect considerable conceptual and social-scientific refinement, but also chart an unacknowledged sociopolitical process, the "tearing away of people from place" (which was also a tearing of people away from non-modern and unmanaged social places), reconfiguring them as movable and substitutable elements in policy strategies (Legg 2005: 137; Foucault 2009). The identification of "populations at risk," or populations which pose risks, is but the latest development in this history. The categories used by demographers, census-takers, policymakers, epidemiologists, and the like "affect the people classified," and those effects, in turn, "change the classifications" (Hacking 2006: 23). The history of population discourse is dogged by temptations to treat population categories as actual objects-discrete, decontextualized and available to study and intervention-and to personalize those objects. These temptations should be, and are, resisted in the name of good science and democratic policy, but cannot be banished by refinement of theory and methods alone, because their actual source lies elsewhere. Concern about risk factors affecting food supply may also produce a second-order risk- "securitizing" the topic of food security, deflecting critical reflection from technological or management strategies, which displace civic rights or social justice in the interests of centralized planning and control.

It is not only the combination of project orientation with fear that is problematic. Good ideas and good science can be misappropriated or misapplied in optimistic, single-focused big-solution projects, which often attract major funding. To treat food security, or even food democracy, as system or population problems requiring top-level expertise in organizational, economic, or technological matters can illuminate opportunities and challenges worth considering. But (to engage in a little prospective speculation of another sort) is it possible that can-do optimism-like collective anxiety, both driven by urgency to address unstable and complex intersections of climatic, geopolitical, economic, and legitimation crises - could decouple planning from critical and contextual reflection, especially if the latter highlights the discomforting vulnerability of planning to blind spots? Could a kind of simulacrum of science result, justifying desperate and repetitive measures to reassert organizational and system control and contain threats? A comparison of food security proposals advanced by the 2011 Foresight report, the FEC Food Justice Report (FEC 2010), Heinemann (2009), or Swaminathan (2010) to, say, the development model advanced with single-minded intensity by Jeffrey Sachs and his supporters (Munk 2013) might be instructive.

6. However, Physiocrats were also agrarian thinkers, and thus a recallable resource for contemporary ecological thought. 


\section{Conclusion}

It is a saving irony that rational analyses of threats to food security, even if they position human instrumental agency as ontologically central, point increasingly to limits of human knowledge and agency, and the social and technological systems it produces, to the limiting consequences of treating the environment as a resource store or waste dump, and to constraints on the practical extent to which we (whoever "we" are) can extend those limits or plan exhaustively for security. There is a growing awareness that both natural and human systems were often misrecognized in the course of modernization. While the Foresight report calls for pragmatic and decisive action involving high-level international co-ordination, it emphasizes that " $[\mathrm{t}]$ he food system is not a single designed entity, but rather a partially self-organised collection of interacting parts," and that policymakers need to "take a broader perspective than hitherto" (e.g., recognizing ecosystem contexts) to confront its challenges (Foresight 2011: 4, 10) — a sentiment echoed by Swaminathan (2010). Such statements indicate a growing sense that defining human relations as discrete and manipulable systems offers both insight and peril. But that insight could be short-circuited by intensification of technocratic control interventions in response to environmental, demographic, and social disruption, or by hubristic Big Idea projects, when these are coupled with demands that they be exempt from "irrelevant" questioning. Failure of such interventions could incite, in both political and expert circles, a rage at convenient scapegoats instead of sober second thought.

If the dangers of language and of action are linked, then ontological concerns are practical issues, not philosophical window-dressing: what is taken for granted about human beings and agency in talk about food systems can have real effects. What might result if such systems were treated not only as objects of control or manipulation but as constitutive environments, within which we live but which also penetrate and live us? Might it be helpful to examine critically how the ends of food security (e.g., sustaining human life) are discursively constructed or framed; to consider ways to talk of and act toward "life" itself other than as a combination of abstract ends and management targets? The challenge of food security is not only understanding and intervening in incredibly complex systems and their interactions, but of attending to how that world and its inhabitants are produced as meaningful entities in speech and action. If, as the French philosopher Jacques Lacan once remarked, the unconscious is structured like a language (Miller 1999: 48), can it also be said that food security discourse is located in situations and relations which may constitute a social unconscious and reproduce a duality of focused attention and presuppositional blindness? If so, the search for "evidence-based solutions" to food security issues needs to be accompanied by inquiry into what counts as evidence (and evidence of what); how evidence is framed, delimited, and judged; how researchers are implicated in its production as a social process; how research and its communication affect what is studied; how research might not only inform practical solutions but also frame what is and is not identifiable and definable as a solution. Admittedly, doing so is made more difficult now by constituencies which dismiss politically inconvenient scientific evidence-or, conversely, dismiss critical inquiry as having no practical bearing on scientific work.

In a recent discussion of sustainable intensification as a food security option (a term central to the 2011 Foresight report), Sue Dibb brushes aside linguistic concerns: "Behind the language lie differing views and assumptions, but focusing the debate on the linguistics misses a golden opportunity to truly understand the challenges and explore the choices we can make to ensure a food system that is

7. Systems can also be represented as not systems, decontextualized and defined as techniques instead. For example, the (good) environmental footprint of "no-till" agriculture depends on an extended but often takenfor-granted complex of technological, energy, and chemical inputs. 
fair for people, animals and the planet" (2012: 3). There is a certain sense in which Dibb's comment seems self-evident: let's get beyond linguistic navel-gazing to true understanding of real choices. From another perspective, the comment is breathtaking. Do we not make choices, understand challenges, and formulate what fairness is only in and through language? The real and the true exist in their production in language and action: language use is practical ontology and practical epistemology. Ontologies "make" us, defining necessary ways of being; epistemologies orient us by defining how reality or truth can be known and acted on. But they do so through their practical realization in located statements and acts. To assume that there is a "we," or a "real," that somehow can be separated from language and life, and apprehended directly, is to ignore how linguistic practices reveal or blind, define possibility or impossibility, and designate the sensible or frivolous, within frames that remain unseen and unstated because they are seen and spoken through.

Marilynne Robinson (2012) identifies a "habit of aggressive fear" in the economic rationalism of austerity programs advanced as necessary solutions to recent economic crises:

Rationalism is forever settling on one model of reality; reason tends toward an appraising interest in things as they come. Rationalism projects, and its projections typically fill it with alarm because of the inadequacy of its model, which, to the rationalist mind, appears as the perversity of the world. To this mind, every problem is systemic, therefore vast and urgent (56).

But Robinson is not rejecting reason, science, or planning per se but targeting an unreasonable practice of rationality that can infect them. This rationalism declares ontological war of sorts when coupled to claims that alternative conceptions of, say, food security or human welfare must necessarily be dispensed with because they do not fit the terms set by a project, a singularly focused mode of controlling, mitigating, or solving "the problem." To be fair, even Gwynne Dyer (2012) does not advocate this: he is trying to get readers to pay attention to the magnitude of looming food security crises. The Foresight report explicitly concludes that "policy options should not be closed off," especially not on a priori grounds (Foresight 2011: 166). Swaminathan's food security proposals (2010), similarly, seek to open up a more contextually sensitive approach incorporating social justice and ecological, as well as genetic and technological, dimensions of food production. But beyond consideration of a wider range of factors and options, there is also a need to attend to food security proposals critically as ways of seeing and saying that not only represent but construct crises and opportunities; to attend to the enigmas that we and our works produce despite our efforts to be definitive. I have targeted technocratic language here, but this language is not the private property of technocrats or technocratic entrepreneurs: non-technocrats also ask, in abstract terms, "how we can save the world" or "how we can plan for climate change." All of us are plunged to some extent into the planner's nightmare: how to account for all the contingencies and their interactions, at all the levels at which "the problem" manifests.

However, it is important not to slip into a sort of linguistic determinism. The imposition of a particular way of making sense of food is not like installing software, and will not necessarily guarantee predictable reproduction (Welker 2012). Nor will embedding biotechnological, management, or economistic language within an ecological perspective necessarily lead to a capture of ecology by systems language (my concern about the language of the 2011 Foresight report notwithstanding)—nor, conversely, of science by folklore (as scientists might fear). Such mixtures might instead generate epistemological, ontological, or political hybrids in which the meaning of terminology from different sources is modified, but not necessarily travestied, in a new deployment. These outcomes will depend as much on cultural, economic and institutional politics as on scholarship or science. Thus, it is as important to pay close attention to possible future meanings as to legacy ones, and to 
practical contexts of their employment. Further, the natural, social, and policy sciences, while they cannot by themselves comprehensively critique ontologies, discursive practices, or politics (because they are themselves embedded in them), can nonetheless play a critical role in public discussions of food security. A trend toward specialization has distanced academic science both from public debate and from critical reflexivity, and has made it vulnerable to misappropriation. But that very specialization becomes a strength when painstaking scientific examination catches gaps or mistaken inferences in big-picture generalizations ... if such examination can be made public in ways that make it harder for governments, the media, and development industry stars to ignore it. Thus, interrogation of the language of "saving the world" or "securing our food future" goes beyond abstractions or ideological tit-for-tat to entail active scrutiny — scientific, philosophical, and practical — of the location, orientation, standards, and consequences of inquiry, representation, and action. Technocratic or economistic approaches to food security that exclude such scrutiny may imperil the future of the human world as much as environmentalist romanticism is alleged to. If food security crises are conceivable as eco-social crises, then they require that the commitments of food practices, policy, and research, and also their social reproduction, be opened up to democratic conversation (Johnston and Baker 2005).

This has implications for law, politics, and policy, as well as science. An alternative to the proclamation of abstract food rights or the imposition of top-down projects and planning is the building of a civil commons to reclaim social spaces, and fields of action in which to develop a new practical ecology of political life and the politico-legal innovations to facilitate it and to challenge the "dominance of instrumental rationality and market regulation" over practical-ethical, aesthetic, and other forms of rationality (Johnston 2006: 62; Sumner 2012; Winson 2013). Civil commons advocacy is closely tied to urban agriculture, co-operative, and food democracy initiatives, and Johnston represents it as communicative and connective, reasserting social control over use values or means of subsistence "for the ends of maximizing life and social justice," in a "counter-globalism based on alternative forms of civil-commons regulation and management" (2006: 61, 62-63). What is intended here by terms like social control, life, or management, is what a civil commons conversation would unpack, not impose. Describing a civil commons in general terms, as I do here, may make it appear impractical precisely because it makes sense in action, in specific situations, and resists abstraction (thus opening to discussion what the "practical" is, and who gets to define it). To its credit, the Foresight report, despite a very different orientation, does not foreclose on such a commons; rather, it advises that policy options be kept open and that the planning and deployment of new technologies involve "open and transparent decision-making." It also acknowledges that "[f]ood is so integral to human wellbeing that discussions of policy options frequently involve issues of ethics, values and politics," and that "[a]chieving a strong evidence base in controversial areas is not enough to obtain public acceptance and approval - genuine public engagement and discussion needs to play a critical role" (Foresight 2011: 166). Swaminathan's eclectic assembly of perspectives, intellectual resources, and language make his work (2010) also a candidate for civil-commons discussion, if read forward for its fluidity rather than back into a Green Revolution box. Participation in a civil commons may not settle definitively questions about how to understand, research, plan for, or act on food security issues, nor guarantee expected outcomes. But it would heighten awareness of what success could mean, and to whom; whether "definitive" interventions might allay or heighten peril, and how questions of scale are more than technical matters. It might also relieve an obsession with the planner's nightmare if such participation opens up planning "for all the levels" to multi-level and multi-scale self-organizing action which does not entail a pre-fixed definition of food security "realities" nor a singularly responsible form of agency to address them. 
Complicating food security: Definitions, discourses, commitments

\section{Acknowledgements}

I thank members of the Prentice Institute for Population and Economy, and the anonymous reviewers, for their very helpful comments on this article in its various stages of preparation.

\section{References}

Albritton, R. 2012. Two great food revolutions: The domestication of nature and the transgression of nature's limits, in Critical Perspectives in Food Studies, edited by M. Koç, J. Sumner and A. Winson. Don Mills ON: Oxford University Press Canada, pp. 89-103.

Alexander, J.K. 2008. The Mantra of Efficiency: From Waterwheel to Social Control. Baltimore: Johns Hopkins.

Barnes, G. 2009. The evolution and resilience of community-based land tenure in rural Mexico. Land Use Policy 26(2):393-400.

Beck, U. 2002. The terrorist threat: World risk society revisited. Theory, Culture \& Society 19(4):39-55.

Bernstein, W. 2010. The Birth of Plenty: How the Prosperity of the Modern World was Created. New York: McGraw-Hill.

Bonner, K. 1997. A Great Place to Raise Kids: Interpretation, Science, and the Urban-Rural Debate. Montreal and Kingston: McGill-Queen's University Press.

Borlaug, N. 2000. The Green Revolution Revisited and the Road Ahead. Special 30th Anniversary Lecture. Oslo: The Norwegian Nobel Institute, September 8. Transcription at http://www. nobelprize.org/nobel_prizes/peace/laureates/1970/borlaug-lecture.pdf.

Brown, L.R. 2011. World on the Edge: How to Prevent Environmental and Economic Collapse. New York: Earth Policy Institute/W. W. Norton \& Company.

Burgis, T., and J. Blas. 2009. Madagascar scraps Daewoo farm deal. FT.Com, Financial Times, March 18. Accessed October 30, 2012, at http://www.ft.com/intl/cms/s/0/7e133310-13ba-11de-9e320000779fd2ac.html\#axzz2AnkIcsN2

Centre for Studies in Food Security, Ryerson University. Accessed October 10, 2012 at http://www. ryerson.ca/foodsecurity/.

Coff, C., M. Korthals, and D. Barling. 2008. Ethical traceability and informed food choice, in Ethical Traceability and Communicating Food, edited by C. Coff, D. Barling, M. Korthals, and T. Nielsen. Dordrecht: Springer.

Cross, A. 2012. Most extensive beef recall in Canadian history expanded again. National Post, October 2. Accessed 30 October 2012 at http://news.nationalpost.com/2012/10/02/most-extensive-beefrecall-in-canadian-history-expanded-again/

Darnton, R. 1984. The Great Cat Massacre, and Other Episodes in French Cultural History. New York: Basic Books.

De Soto, H. 2000. The Mystery of Capital: Why Capitalism Triumphs in the West and Fails Everywhere Else. New York: Basic Books.

Dibb, S. 2012. Sustainable intensification: unravelling the rhetoric. Editorial. Food Ethics 7(2). Special issue, Sustainable Intensification: Unravelling the Rhetoric. Food Ethics Council. Available at www. foodethicscouncil.org/system/files/summer2012_web.pdf 
Douglas, M. 2002. The abominations of Leviticus, in Purity and Danger: An Analysis of the Concepts of Pollution and Taboo, edited by M. Douglas. London: Routledge.

Draper, J. 2011. Rift in paradise: Africa’s Albertine Rift. National Geographic, November. Accessed October 30, 2012 at http://ngm.nationalgeographic.com/2011/11/albertine-rift/draper-text

Durkheim, E. [1895] 1982. The Rules of Sociological Method. New York: Free Press.

Dyer, G. 2009. Climate Wars. Toronto: Vintage Canada.

. 2012. How global civilization will get through the 21st century. straight.com, 20 March 20. Accessed 7 October 2012 at http:/ / www.straight.com/article-639246/vancouver/gwynne-dyerhow-global-civilization-will-get-through-21st-century (subsequently moved to http://www.straight. $\mathrm{com} /$ news/gwynne-dyer-how-global-civilization-will-get-through-21st-century)

FAO. 2003. Trade Reforms and Food Security: Conceptualizing the Linkages. Rome: Food and Agriculture Organization of the United Nations, chapter 2. Accessed Nov. 18, 2014 at http://www.fao.org/3/ay4671e.pdf.

FEC. 2010. Food Justice: The Report of the Food and Fairness Inquiry. Brighton, UK: Food Ethics Council. Available at www.foodethicscouncil.org/system/files/FoodJustice_reportweb.pdf

Foresight. 2011. The Future of Food and Farming: Final Project Report. London: The Government Office for Science, HM Government.

Foucault, M. 2009. Security, Territory, Population: Lectures at the College de France, 1977-1978. London: Picador. 1994. The Order of Things: An Archaeology of the Human Sciences. New York: Vintage.

Fraser, E.D.G., and A. Rimas. 2010. Empires of Food: Feast, Famine and the Rise and Fall of Civilizations. New York: Free Press.

Glassner, B. 2007. The Gospel of Food: Everything You Think You Know About Food is Wrong. New York: HarperCollins.

Gottlieb, R., and A. Joshi. 2010. Food Justice. Cambridge MA: MIT Press.

Hacking, I. 1986. Making up people, in Reconstructing Individualism: Autonomy, Individuality, and the Self in Western Thought, edited by T.C. Heller, M. Sosna, and D.E. Wellbery. Stanford CA: Stanford University Press, pp. 222-236.

Heinemann, J.A. 2009. Hope Not Hype: The Future of Agriculture Guided by the International Assessment of Agricultural Knowledge, Science and Technology for Development. Penang: Third World Network.

Hewitt de Alcantara, C. 1974. The 'Green Revolution' as history: the Mexican experience. Development and Change 5(2):25-44.

Huppert, G. 1998. After the Black Death: A Social History of Early Modern Europe. 2nd edn. Bloomington: Indiana University Press.

Johnston, J. 2006. Who cares about the commons? in Nature's Revenge: Reclaiming Sustainability in an Age of Corporate Globalization, edited by J. Johnston, M. Gismondi, and J. Goodman. Toronto: Broadview, pp. 39-71.

Johnston, J., and L. Baker. 2005. Eating outside the box: FoodShare's good food box and the challenge of scale. Agriculture and Human Values 22:313-325. 
Complicating food security: Definitions, discourses, commitments

Johnston, J., A. Biro, and N. MacKendrick. 2009. Lost in the supermarket: The corporate-organic foodscape and the struggle for food democracy. Antipode 41(3):509-532.

Jung-a, S., and C. Oliver. 2008. Daewoo to cultivate Madagascar land for free. ft.com/global economy, Financial Times, November 19. Accessed October 29, 2012, at http://www.ft.com/cms/ s/0/6e894c6a-b65c-11dd-89dd-0000779fd18c.html\#axzz2AnkIcsN2

Koc, M., and J.A. Bas. 2012. Canada's Action Plan for Food Security: The interactions between civil society and the state to advance food security in Canada, in Health and Sustainability in the Canadian Food System: Advocacy and Opportunity for Civil Society, edited by R. McCrae and E. Abergel. Vancouver: UBC Press, pp. 173-203.

Miller, J.-A. (ed.). 1999. The Seminar of Jacques Lacan. Book XX. New York: Norton.

de Larrinaga, M., and M.G. Doucet (eds.). 2010. Security and Global Governmentality: Globalization, Governance and the State. London: Routledge.

Latour, B. 2000. On the partial existence of existing and nonexisting objects, in Biographies of Scientific Objects. Chicago: University of Chicago Press.

Legg, S. 2005. Foucault's population geographies: Classifications, biopolitics and governmental spaces. Population, Space and Place 11:137-156.

McKeon, N. 2013. Food Security: From Crisis to Global Governance. London: Routledge.

Montanari, M. 1996. The Culture of Food. Oxford: Blackwell.

Moyo, D. 2009. Dead Aid: Why Aid Is Not Working and How There Is a Better Way for Africa. New York: Farrar, Strauss, and Giroux.

Munk, N. 2013. The Idealist: Jeffrey Sachs and the Quest to End Poverty. Toronto: McClelland \& Stewart.

Neoclous, M., and G.S. Rigakos (eds.). 2011. Anti-Security. Ottawa: Red Quill Books.

Novak, M. (ed.). 2008. The Age of Projects. Toronto: University of Toronto Press.

Ostria, M. 2013. How U.S. Agricultural Subsidies Harm the Environment, Taxpayers and the Poor. Issue Briefs (Environment) No. 126. Dallas-Washington: National Center for Policy Analysis. http://www.ncpa. org/pub/ib126, accessed November 18, 2014.

Parayil, G. 2003. Mapping technological trajectories of the Green Revolution and the Gene Revolution from modernization to globalization. Research Policy 32(6):971-990.

Rakotondrainibe, M. 2012. Madagascar: Projet Daewoo, le retour? Reflexions, 16 January. Accessed 30 October 2012 at http://reflexiums.blogspot.ca/2012/01/madagascar-projet-daewoo-le-retour.html.

Ramp, W., and T.W. Harrison. 2012. Libertarian populism, neoliberal rationality, and the mandatory Long-form Census: Implications for sociology. Canadian Journal of Sociology 37(2):273-294.

Reuters. 2012. UPDATE 4-Ukraine confirms wheat export ban. New York: Thomson Reuters, October 24. Accessed October 27, 2012, at http://www.reuters.com/article/2012/10/24/ukraine-grainwheat-idUSL5E8LO2SM20121024.

Robinson, M. 2012. When I Was a Child I Read Books. Toronto: HarperCollins.

Saunders, D. 2011. Talking to spies about farming: The danger of seeing food as a 'strategic asset.' Accessed 16 November 2012 at http://dougsaunders.net/2011/01/food-security-egypt-tunisiacsis/. 
Sawday, J. 2008. Engines of the Imagination: Renaissance Culture and the Rise of the Machine. London: Routledge.

Shiva, V. 1992. The Violence of the Green Revolution: Ecological degradation and political conflict in Punjab. New Delhi: Zed Press.

Sintchenko, V. n.d.[2005?]. Food Safety: Monitoring and Surveillance Systems. Sydney Institute for Emerging Infectious Diseases \& Biosecurity. Sydney, Australia: The University of Sydney. Available online at sydney.edu.au/seib/PDFs/seib12vitali-sintchenko.pdf.

Smith, D.E. 1974. The social construction of documentary reality. Sociological Inquiry 44: 257-268.

Stephen, L. 1998. Between NAFTA and Zapata: Responses to restructuring the commons in Chiapas and Oaxaca, Mexico, in Privatizing Nature: Political Struggles for the Global Commons, edited by M. Goldman. London: Pluto Press.

Sumner, J. 2012. Conceptualizing sustainable food systems, in Critical Perspectives in Food Studies, edited by M. Koç, J. Sumner, and A. Winson. Don Mills ON: Oxford University Press Canada, pp. 326-336.

Swaminathan, M.S. 2010. Science and Sustainable Food Security: Selected Papers of M.S. Swaminathan. Singapore: World Scientific Publishing.

Toronto Star. 2012. XL Foods management taken over by arm of Brazilian food giant, Toronto: thestar. com, October 18. Accessed October 30 at http://www.thestar.com/news/canada/politics/ article/1273088--xl-foods-to-be-managed-by-brazilian-subsidiary.

USDA, Economic Research Service. 2012. Food Security in the U.S. Accessed 27 October 2012 at http:// www.ers.usda.gov/topics/food-nutrition-assistance/food-security-in-the-us/measurement.aspx.

Vernon, James. 2007. Hunger: A Modern History. Cambridge MA: Harvard/Belknap.

Visser, M. 2008. The Gift of Thanks: The Roots, Persistence and Paradoxical Meanings of a Social Ritual. Toronto: HarperCollins.

Walby, K., and S.P. Hier. 2005. Risk technologies and the securitization of post-9/11 citizenship: The case of national ID cards in Canada. Socialist Studies / Études socialistes 1(2):7-31. Available online at www.socialiststudies.com/index.php/sss/article/download/44/41.

Weber, M. 1968. The meaning and presuppositions of modern capitalism, in Max Weber on Charisma and Institution-Building: Selected Papers, edited by S.N. Eisenstadt. Chicago: University of Chicago Press.

Welker, M. 2012. The Green Revolution's ghost: Unruly subjects of participatory development in rural Indonesia. American Ethnologist 39(2):389-406.

Westerman, F. 2010. Engineers of the Soul: In the Footsteps of Stalin's Writers. London: Harvil Secker.

Wilson, H.T. 1977. The American Ideology. London: Routledge.

- 2001. Bureaucratic Representation: Civil Servants and the Future of Capitalist Democracies. Leiden: Brill.

Winner, L. 1986. Do artifacts have politics? in The Whale and the Reactor: A Search for Limits in an Age of High Technology, edited by L. Winner. Chicago: University of Chicago Press, pp. 19-39.

Winson, A. 2013. The Industrial Diet: The Degradation of Food and the Struggle for Healthy Eating. Vancouver: UBC Press.

Zuberi, T., and K.J.A. Thomas. 2012. Demographic projections, the environment and food security in sub-Saharan Africa. Working Papers 2012-001, United Nations Development Programme, Regional Bureau for Africa (UNDP/RBA). 